\title{
Deferred fees for universities
}

\section{Neil Shephard ${ }^{1}$}

This is a response to the call for evidence "Proposals for a new higher education system" by the Browne Review on "Higher Education Funding and Student Finance."

Summary: I will argue for a simpler, fairer, more fiscally responsible and flexible form of university funding and student support. This system is designed to encourage a diverse higher education sector where high quality provision can flourish. The main points of the new system are:

1. Make student financial support available to cover all tuition and a modest cost of living.

2. Allow graduates to repay according to earnings with protection for poorer graduates.

3. Call HEFCE teaching grants "scholarships" and make students aware of their value.

4. Cap the level of funded fees plus HEFCE grant at the current level.

5. Allow universities to charge deferred fees.

a. When they are paid the money goes to the student's university not to the state. These fees have no fiscal implications.

b. Bring some of the cash flow from deferred fees forward by working with a bank.

6. In the long-run move to making the cost of living support simpler by

a. Providing more realistic cost of living support for all students.

b. Removing means-tested university bursaries for cost of living expenses.

c. Removing means-tested grants to students provided by the state.

This builds on England's higher education structure. The changes are simple to implement. It would set up a stable funding structure for our universities \& provide the financial support our students need.

\section{A new higher education funding structure}

The system will have four parts. (i) financial support for students, (ii) support for tuition, (iii) a longrun move to a simple cost of living system, (iv) encouraging early payments. Point (i) underpins the other parts, while (ii), (iii) and (iv) can be considered entirely separately.

\subsection{Financial support for students}

Whenever I refer to "financial support" I will mean the following. Students can opt to take out a financial support package to fully or partially fund their fees and/or cost of modest living. Whatever the size of the financial support package, students will be offered payment terms as graduates which are $9 \%$ of earnings above $f 15 \mathrm{k}$ until they have paid back the full amount (net present value) of support ${ }^{2}$. The parts of support package which are not repaid due to low earnings are forgiven after

\footnotetext{
${ }^{1}$ This version: 10th May 2010. Professor Neil Shephard FBA, Professor of Economics, University of Oxford and Director, Oxford-Man Institute, Eagle House, Walton Well Road, Oxford OX2 6ED, UK. Email: neil.shephard@economics.ox.ac.uk.

${ }^{2}$ For simplicity of exposition I have not described the impact of changing the payment percentage, the $f 15 \mathrm{k}$ threshold or different interest rates. Dearden, Goodman, Kaplan and Wyness (2010) provide a thorough discussion of those issues, while Shephard (2010) discussed lowering the payment percentage and increasing the interest rate.
} 
25 years. The interest rate should be the state's cost of borrowing (currently $2.2 \%$ real). The system is run through the Student Loan Company (SLC) ${ }^{3}$.

\subsection{Support for tuition}

\subsubsection{HEFCE grant for each student}

Currently all universities receive upfront the standard HEFCE teaching grant and subject premiums on a per student basis. This makes sense as education on average generates positive externalities and so should be subsidised by the state.

The HEFCE grant should be rebranded so students explicitly recognise it. It should be called, for example, a "scholarship" demonstrating how the state invests in educating students. Currently this support is largely invisible to students, which undermines the system's popularity.

\subsubsection{Tuition fees}

Students would be charged fees. Financial support would be available in all cases to pay these, although some students and their families may wish to pay upfront. This makes sense as students derive a private benefit from the education and so, if they can afford it as graduates, it is appropriate for them to make a contribution. This will mean education will continue to be freely available to students.

\subsubsection{Funded fees}

Fees will have up to two parts: "funded fees" and "deferred fees".

Funded fees are paid upfront to the university by the student either directly, or by the student taking out financial support for fees from the state. Any repayments for support will go to the state, which takes the risk the graduates will have their fees forgiven. Hence the university is guaranteed to receive the funded fee immediately. Funded fees must be capped, otherwise the state has unlimited liabilities ${ }^{4}$. I would recommend that the HEFCE grant plus funded fee cap is kept at the current level.

\subsubsection{Deferred fees}

To allow for genuinely variable fees universities should be allowed to charge "unfunded fees" if they wish to. These fees can be paid to the university upfront by parents or by graduates over time through the financial support system whose terms are entirely unaltered by their introduction. Note graduates with a deferred fee do not make higher monthly repayments. They merely repay for longer. The last piece of those repayments will go to the university. At no point does the state pay for unfunded fees. The terms on which the fees are paid are the same as other parts of financial support, although they are better called variable "deferred until you can pay" fees. I will call them "deferred fees" for short.

The university takes the risk that graduates' earnings will be low and so have their deferred fees forgiven. So it incentivises them to generate high private benefit for their students, to provide a value-added education that will translate into a higher income. The state plays no role and the level of these fees has no impact fiscally. One university's deferred fee has no financial implication for any other university and deferred fees are paid by graduates not students. Indeed one substantial

\footnotetext{
${ }^{3}$ It would be more accurate to name this company the Student Support Company.

${ }^{4}$ If the cap was to rise then it will be rational for universities to all set their fees at the cap, as the state guarantees they will receive the cap. Hence the state will have encouraged universities to charge high fees.
} 
advantage over the current system is that universities will not move to a single "cap" level of fees. It is only worth the universities charging deferred fees if they believe their graduates will have the income levels to support them.

As a person working at a university I find this attractive. The university would be investing (i.e., teaching without demanding upfront payment) in the future prosperity of its graduates, while looking after those that do not have high future incomes.

These deferred fees should be junior to the living costs and funded fees support from the state, so payments by graduates first go to the state to pay their costs and then to the university to pay the unfunded fees. The SLC would collect the income for the university in the usual way. In effect the university would own a particular slice of their loan book ${ }^{5}$. As the deferred fees are junior, graduates will need quite high earnings to pay them. Poorer graduates will have them entirely forgiven.

A university's deferred fee delivers it two new income sources: upfront payments and 25 years of annual part payments from their better-off graduates. The former raises no new issues for universities as it is simply an additional cash payment. The latter is more challenging. In Section 2.2 I will show efficient ways in which this cash flow can be capitalised by selling a bond to a bank (or borrowing from a bank) so that the resulting resources can be spent on education immediately.

\subsection{A simple cost of living system}

Cost of living calculations are challenging as students have very different lifestyles, number of weeks at university and patterns of work while at university. Some areas are expensive to live in. However, if we want to ensure all students can have access to higher education and to lower the risk of high dropout rates at university, then the state should be prepared to support a modest cost of living for everyone.

Warwick University's website is quite typical in its recommendations: "Undergraduate students will need around $£ 7,000$ to cover living costs (excluding fees) for the nine months from October to June each year." Bristol University suggests a minimum range of $£ 6.2-f 7.2 k$, Oxford Brookes suggests $£ 8.4 k$ and the London School of Economics suggest a minimum of $f 1 k$ a month ${ }^{6}$.

What is clear is that the current level of financial support for many students is inadequate and is very complicated ${ }^{7}$. This suggests having a long-term goal of developing cost of living financial support of between $f 6.8 \mathrm{k}-\mathrm{f} 8 \mathrm{k}$ a year, available to all UK students. By having a sensible interest rate, the cost to the state of student support falls dramatically. We will quantify this later. This implies less need to aggressively ration such support using means testing or other criteria, allowing us to develop a much simpler, fairer and more fiscally efficient system. This suggests removing all forms of cost of living

\footnotetext{
${ }^{5}$ Note that under current EU law, other-EU students cannot require the UK state to provide them with living cost support but can be charged fees. So they will be immediately paying their funded fees followed by their deferred fees through the financial support system. ${ }^{6}$ From their websites, downloaded 4/10. See also National Union of Students (2009b, p14) who estimate average rent at $£ 3.9 \mathrm{k}$, travel at f0.6k and food at $£ 1.7 \mathrm{k}$. NUS (2010) present a survey of rental costs for students.

${ }^{7}$ Table $1 \mathrm{~b}$ of the SLC's data release (25/11/09) shows the balance between grants and loans for the UK. If the family earnings are below $£ 25 k$ then students get a loan of $£ 3.5 k$, a grant of $£ 2.9 k$ from the state and a minimum bursary from a university of $£ 0.3 k$ (it averages $f 0.9 k$, see Office of Fair Access (2009, p. 18, footnote 7)). The minimum is thus $f 6.7 k$ and the average is $f 7.3 k$. By the time earnings reaches $f 50 \mathrm{k}$ a year then the grant has tapered away and the maximum loan is $f 3.6 \mathrm{k}$ with the rest unfunded. The SLC's Table 3 suggests around $33 \%$ of students receive a full grant ( $£ 2.9 \mathrm{k}$ ) and roughly $21 \%$ a partial grant. In addition universities use around a significant fraction of their fee income from students to fund university bursaries. The structure of these bursaries vary dramatically between institutions. At Newcastle University it is $£ 1.5 k$, University Brighton offers $£ 1,080$.
} 
grants, bursaries (cash gifts given to some students funded from fee income paid by other students) and sliding scales, so that all students are treated in the same way.

This would reduce the liquidity constraint some young people face when they decide if they wish to go to university and makes the system much simpler to administer, so reducing the chance of additional SLC implosions that put students at risk. It also makes the system significantly cheaper to run: grants cannot be recovered from better off graduates while the vast majority of student financial support will be. Further it is simpler to explain to potential students so they precisely know the deal before accepting a place at university. This approach is attuned with the comments made in the $2^{\text {nd }}$ round call for evidence by the Browne Review ${ }^{8}$. Finally, by removing the current system of university bursaries, net fee income will rise, reducing the need for many universities to press for an increase in the level of their fees.

\subsection{Encouraging earlier payment}

At the moment around $15 \%$ of fees are paid upfront by UK students ${ }^{9}$. It is in the financial interest of all stakeholders to raise the amount of upfront or early payments by wealthy parents, employers or philanthropy when they can afford it. Why? (i) For students, it reduces their aggregate long-run liabilities. (ii) For the state, this reduces the size of their student loan book and reduces the amount of support which will have to be forgiven. (iii) For universities, this provides income upfront and eliminates the risk that graduates will fail to reach the earnings threshold at which they pay deferred fees.

How do we encourage early payment? As many people have argued elsewhere, there are overwhelming reasons for charging an interest rate at the government's cost of borrowing, rather than the much lower inflation rate currently used. This reform should also increase the rate of upfront payments, as this will remove the current arbitrage on the student loan book ${ }^{10}$.

We can reduce the liquidity challenges many families face in writing large annual checks. Utilities typically allow annual bills to be paid by monthly direct debit. There seems no reason why tuition fees cannot be paid or partially paid this way ${ }^{11}$. This would work by having all students automatically covered by the financial support system. But support for fees would only be drawn down if the university did not receive payments for tuition. Further philanthropic or industry sponsored bursaries should focus in the first instance on forgiving student support rather than providing additional cost of living expenses. (Additional cost of living support will be less needed if cost of living support rises to a reasonable level).

\footnotetext{
8 They said the following: "The IFS have analysed the impact of fee and student support changes over the past 16 years to estimate the positive and negative impact of the different elements on participation rates of young people aged 18-19 (using the Labour Force Survey). Their research suggests: a $£ 1,000$ increase in fees results in a 4.4 percentage point fall in participation rates; a $£ 1,000$ increase in loans results in a 3.2 percentage point increase in participation rates; and a $£ 1,000$ increase in grants results in a 2.1 percentage point increase in participation rates... "See www.ifs.org.uk/docs/fees_review.ppt

${ }^{9}$ I do not have reliable data on the percentage of parents/students who pay upfront. With the help of Alison Johnston at the LSE I have managed to get university level data from 4 Russell Group Universities and 1 non-Russell Group University. The variation between institutions is quite modest. Taken together I have the following as yet very rough stylised facts: around $15-20 \%$ of UK based students pay up front; a higher level of other-EU students pay up front than UK students.

${ }^{10}$ Currently the interest rate is $0 \%$ real. Thus if prosperous parents give their child cash to pay for their education upfront then it is rational for the student to put the cash into a tax free indexed linked national savings certificate (which currently pays inflation plus one percent on up to $f 30 \mathrm{k}$ per person), and for the student to take out a student loan of the same value. When the certificate expires then the student loan is repaid, or the certificate is rolled over. In either case the student makes a profit of the real interest rate on the certificate without any risk. So the student can arbitrage the taxpayer by about $f 200$ per year for up to 25 years (in practice it is likely to be for around 10 years). So it is irrational to pay upfront.

${ }^{11}$ SLC receives annual payments from HM Revenue \& Customs so receiving monthly payments would require adjustments.
} 
Likewise graduates might opt to make additional early payments by monthly direct debit. Employers may be able to help either by making payments for their staff directly as part of their compensation for new employees or incentivise their staff to make early payments themselves (e.g. through salary sacrifice). It may be attractive to be able to set up "education savings accounts", which would be drawn upon to pay higher or further education tuition fees. A simple example of such an account would pay inflation $+1 \%$ tax free, the same conditions as index-linked national savings certificates.

\section{Outline of proposed system}

Financial support system for students should be made available to cover all tuition fees and the cost of modest student living. Graduates pay $9 \%$ of earnings above $115 \mathrm{k}$ until they have paid back the net present value (NPV) of their support or are forgiven after 25 years. The interest rate is the state's cost of borrowing.

Each student would receive a visible scholarship for tuition from the state, which would be paid over to the university. This simply rebrands the current HEFCE block teaching grant to universities.

Fees = "funded fees" + "deferred fees", to be paid by graduates.

- The state pays universities funded fees, with no variation across the sector. Graduates pay the state.

- Deferred fees provide a new income stream for universities, allow fee variation between universities. Graduates pay their universities.

- These are fiscally neutral. Poorer graduates don't pay them.

- New sources of university income: upfront payments and a flow of annual payments from their graduates.

- The university can opt to

- Hold the flow of payments on their books, like an addition to their endowment.

- Capitalise the cohort's annual payments by selling a bond or working with a bank, spending the capitalised value on educational provision now.

In the long-run move to making the cost of living support simpler by

- Provide financial support for cost of living of $£ 6.8 k-£ 8 k$ a year per student to any student who wishes to have it. Remove means-testing of loans.

- Remove

- All state grants.

- University bursaries funded through the fee income from other students.

- Philanthropic and industry support should focus on forgiving financial support (i.e. cancelling income contingent support), not giving students more cash for living expenses.

Encourage upfront or early payments by students, their benefactors or by graduates. 


\section{Some financial analysis of the proposed changes}

\subsection{Funded fees and cost of living}

\subsubsection{Who pays now}

Although there now seems to be a consensus in favour of removing the interest subsidy from student financial support, it is useful to quantify the current set-up so that we have a benchmark.

Detailed analysis of the financial support system is given in the Appendix. It shows that currently the average loss the state makes per year per student on those to whom it gives cost of living financial support is forecasted to be $f 0.60 k$ net present value (NPV). The average loss on fees is $f 0.94 k$. Therefore the average state loss is $£ 1.54 k$ out of $£ 6.8 k$ ( $£ 3.2 k$ in fees plus $£ 3.6 k$ in average cost of living support. Thus this is a $23 \% \operatorname{loss}^{12}$ ). This applies to $85 \%$ of students as $15 \%$ pay upfront.

In the public accounts the forecasted losses are added to the Higher Education Resource Accounting Budget (RAB), which is the committed non-cash educational spending. Then roughly $1 / 25$ th of this is drawn down each year and appears as cash spending in the accounts in the year of the draw down. Hence making the financial support system more efficient only marginally improves the current deficit (Public Sector Net Borrowing), but it does improve the public finances over the long-run as the RAB will accumulate up to a large number. See Barr and Johnston (2010, Appendix) for more details and other features of student support which affects the RAB and deficit.

\begin{tabular}{|c|c|c|c|c|c|c|}
\hline & \multicolumn{6}{|c|}{ NOW } \\
\hline & \multicolumn{2}{|c|}{ Tax payer } & & \multicolumn{3}{|c|}{ Families } \\
\hline Cost of living & Deficit & RAB & Univ & Parents & Grad & Student \\
\hline Maintenance & \multirow{4}{*}{\multicolumn{2}{|c|}{-1.0}} & \multirow{4}{*}{-0.5} & \multirow[t]{3}{*}{-1.0} & \multirow[t]{3}{*}{-2.6} & 4.1 \\
\hline State grant & & & & & & 1.0 \\
\hline Univ bursary & & & & & & 0.5 \\
\hline Tuition & & & & \multirow{3}{*}{-0.5} & & \\
\hline Fees & \multirow[b]{2}{*}{-4.1} & \multirow[t]{2}{*}{-0.8} & 3.2 & & \multirow[t]{2}{*}{-1.9} & \\
\hline HEFCE & & & 4.1 & & & \\
\hline \multirow[t]{2}{*}{ All costs } & -5.1 & -1.3 & 6.8 & -1.5 & -4.5 & 5.6 \\
\hline & \multicolumn{2}{|c|}{-6.4} & $\underline{6.8}$ & & $\underline{-0.4}$ & \\
\hline
\end{tabular}

Table 1a. The financial position now. Who pays what? Each number averages over the population, e.g. about $15 \%$ of families pay upfront, so they contribute on average $0.15 \times £ 3.2 \mathrm{k}=£ 0.48 \mathrm{k}$ to paying fees. The HEFCE grant for a band $D$ subject (typically humanities and social science) is around $52.8 \mathrm{k}$ and attracts no subject premium. Averaging the level of grant over all subjects then it rises to around $£ 4.1 \mathrm{k}$ per student per year. It is this number which is most relevant to the deficit in practice. Source: author's calculation.

Table 1a provides a summary of how student costs divide between the taxpayers, universities and families. Overall students receive on average $55.6 \mathrm{k}$ per year per student cash upfront for living costs. This is below average university living costs and so on average students have to borrow or work. $f 4.5 \mathrm{k}$ is repaid by graduates as they work while $\mathrm{f} 1.5 \mathrm{k}$ is funded by parents. Netted over the long-run then families contribute $\mathrm{f0.4k}$ per student per year for going to university, basically

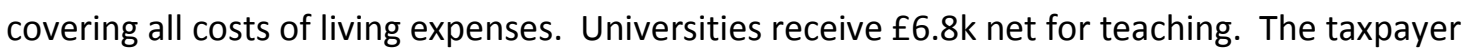

\footnotetext{
12 Using somewhat different data, Dearden et al (2010) also report a 23\% loss rate. The reason the rate of losses is higher for fees is that the state has decided payments first count against their cost of living support and once that is paid off, then the payments go towards fees. This decision makes no financial difference to the state, but impacts the Tables given here. I think for the credibility of the system it would be better to have the following order of seniority: funded fees, cost of living and then deferred fees. Then graduates would get an annual print off of the NPV of the individual items they have paid off so far and a reminder of the value of the scholarships they received.
} 
contributes on average around $f 6.4 \mathrm{k}$ per student per year $^{13}$, although for humanities and social science students the number is more like $f 5.1 \mathrm{k}$.

\subsubsection{Removing the rate subsidy}

If the interest rate subsidy is removed, as advocated by for example Barr (2004), Barr and Johnston (2010) and Laidlaw (2009), then the results alter. The Appendix forecasts that living cost losses fall to about $£ 0.11 k$, fees to $£ 0.38 k$ and overall losses to $f 0.49 k$ per student per year ( $7 \%$ loss). The result overall is presented in the top right hand side of Table $1 \mathrm{~b}$. It shows graduates pay $f 1 \mathrm{k}$ a year more, which reduces the RAB by this amount and leaves the deficit unaltered. Only graduates are affected by this change, not universities or parents. The distributional implications of this change are studied in the Appendix which shows the poorest graduates are entirely protected from the consequence of this change ${ }^{14}$.

\begin{tabular}{|c|c|c|c|c|c|c|}
\hline & \multicolumn{6}{|c|}{ REMOVING RATE SUBSIDY } \\
\hline & \multicolumn{2}{|c|}{ Tax payer } & & \multicolumn{3}{|c|}{ Families } \\
\hline Cost of living & Deficit & RAB & Univ & Parents & Grad & Student \\
\hline Maintenance & \multirow{3}{*}{\multicolumn{2}{|c|}{-0.0}} & \multirow{4}{*}{-0.5} & \multirow[t]{3}{*}{-1.0} & \multirow[t]{3}{*}{-3.1} & 4.1 \\
\hline State grant & & & & & & 1.0 \\
\hline Univ bursary & & & & & & \multirow[t]{4}{*}{0.5} \\
\hline Tuition & & \multirow{3}{*}{-0.3} & & \multirow{3}{*}{-0.5} & \multirow{3}{*}{-2.4} & \\
\hline Fees & & & 3.2 & & & \\
\hline HEFCE & -4.1 & & 4.1 & & & \\
\hline All costs & -5.1 & -0.3 & 6.8 & -1.5 & \multirow{2}{*}{$\begin{array}{c}-5.4 \\
-1.4\end{array}$} & 5.6 \\
\hline & \multicolumn{2}{|c|}{-5.4} & $\underline{6.8}$ & & & \\
\hline
\end{tabular}

Table $1 b$. The financial position after removing the rate subsidy. Otherwise the assumptions are the same as in Table $1 a$.

\subsubsection{Simplifying the "cost of living" support}

I argued above for a simpler support system for cost of living. Here I model the financial implications assuming cost of living support would increase to $f 6.8 \mathrm{k}$ and this would be available to all students. Then the losses to the state would be $£ 0.49 \mathrm{k}$ for maintenance, $£ 0.76 \mathrm{k}$ for fees and $£ 1.25 \mathrm{k}$ in total out of the f10k of student support per year (12\% loss). We froze funded fees, but university net income rises due to the fall in bursaries (obviously the percentage rise will be more significant for those teaching non-premium subjects). The result is given in Table 1c.

\begin{tabular}{|c|c|c|c|c|c|c|}
\hline & \multicolumn{6}{|c|}{ SIMPLIFYING “COST OF LIVING” SUPPORT } \\
\hline & \multicolumn{2}{|c|}{ Tax payer } & & \multicolumn{3}{|c|}{ Families } \\
\hline Cost of living & Deficit & RAB & Univ & Parents & Grad & Student \\
\hline Maintenance & \multirow{2}{*}{\multicolumn{2}{|c|}{-0.4}} & & \multirow[t]{2}{*}{-1.0} & \multirow[t]{2}{*}{-5.4} & \multirow[t]{4}{*}{6.8} \\
\hline Tuition & & & & & & \\
\hline Fees & \multirow{2}{*}{\multicolumn{2}{|c|}{-4.1}} & 3.2 & \multirow[t]{2}{*}{-0.5} & \multirow[t]{2}{*}{-2.1} & \\
\hline HEFCE & & & 4.1 & & & \\
\hline \multirow[t]{2}{*}{ All costs } & -4.1 & -1.1 & 7.3 & -1.5 & -7.4 & 6.8 \\
\hline & \multicolumn{2}{|c|}{-5.2} & 7.3 & \multicolumn{3}{|c|}{-2.1} \\
\hline
\end{tabular}

Table 1c. Removing the rate subsidy \& simplifying the cost of living support. Otherwise the same as in Table $1 a$.

Average student income would increase. Graduates pay back considerably more unless they are poor in which case they are entirely protected. University net income rises without recourse to an increase in fees, as they are no longer funding cost of living from fee income. The taxpayer contributes on average around $f 5.2 \mathrm{k}$ per student per year (down $19 \%$ compared to now), although for humanities and social science students the number is more like $f 2.8 \mathrm{k}$ (down $46 \%$ ).

\footnotetext{
13 In comparison the spending in 2006-2007 for local authority maintained secondary schools was $£ 4$.3k. Source: www.dcsf.gov.uk/rsgateway/DB/TIM/m002001/index.shtml. This is around the same level as the average HEFCE grant.

${ }^{14}$ See Dearden, Goodman, Kaplan and Wyness (2010) for a much more detailed analysis of this change.
} 
Of course we are in financially challenging times and so the state may slice off some of the increase in net university income by reducing the HEFCE grant (which would disappoint universities) and it might swap some HEFCE grant for an increase in fees (which would mean graduates would have to pay the same monthly as now but for longer, but universities would not be affected so long as subject premiums are protected). Both of these steps directly and significantly improve the deficit.

\subsection{Financial analysis of deferred fees}

Deferred fees are paid to the student's university. At no point is the state involved so they are fiscally neutral.

\subsubsection{How much would an average university receive from deferred fees?}

Using the modelling reported in the Appendix, the rates at which graduates pay can be estimated. As the level of fees increases, fewer graduates will be able to pay them off in full and so the yield from the deferred fee will taper off. Table 2 gives the results ${ }^{15}$.

\begin{tabular}{|c|c|c|c|c|c|c|}
\hline \multirow[b]{2}{*}{$\begin{array}{r}\text { Level of deferred } \\
\text { fee }\end{array}$} & \multicolumn{3}{|c|}{$\begin{array}{l}\text { Additional, assumes cost of living } \\
\text { support is } £ 3.6 \mathrm{k}\end{array}$} & \multicolumn{3}{|c|}{$\begin{array}{l}\text { Additional, assumes cost of living } \\
\text { support is } £ 6.8 \mathrm{k}\end{array}$} \\
\hline & $\begin{array}{r}\text { University } \\
\text { income }\end{array}$ & $\begin{array}{r}\text { Parental } \\
\text { payments }\end{array}$ & $\begin{array}{l}\text { Graduate } \\
\text { payments }\end{array}$ & $\begin{array}{r}\text { University } \\
\text { income }\end{array}$ & $\begin{array}{r}\text { Parental } \\
\text { payments }\end{array}$ & $\begin{array}{l}\text { Graduate } \\
\text { payments }\end{array}$ \\
\hline 1,000 & 837 & -150 & -687 & 717 & -150 & -567 \\
\hline 2,000 & 1,639 & -300 & $-1,339$ & 1,398 & -300 & $-1,098$ \\
\hline 3,000 & 2,404 & -450 & $-1,954$ & 2,038 & -450 & $-1,588$ \\
\hline 4,000 & 3,129 & -600 & $-2,529$ & 2,638 & -600 & $-2,038$ \\
\hline 5,000 & 3,818 & -750 & $-3,068$ & 3,201 & -750 & $-2,451$ \\
\hline 6,000 & 4,466 & -900 & $-3,566$ & 3,725 & -900 & $-2,825$ \\
\hline 9,000 & 6,175 & $-1,350$ & $-4,825$ & 5,092 & $-1,350$ & $-3,742$ \\
\hline
\end{tabular}

Table 2. Level of additional income for universities from deferred fees in the long-run and who pay. Computed with the current cost of living support and a boosted level. Negative numbers are those who pay for this. Some of the new income comes from upfront payments and from graduates. The latter will be spread over a 25 year period. All numbers are in NPV.

A significant challenge for universities with deferred fees is that the majority of the income comes with a delay, as their graduates become better off.

\subsubsection{When would the income arrive?}

Using the methods given in the Appendix it is possible to estimate the cash flow to the university from deferred fees. The results are given in Figure 1 for three different levels of deferred fees assuming the level of cost of living support is $f 6.8 \mathrm{k}$. It shows that the income comes from upfront payments initially. Then we wait until graduates reach the age of around 31 and then the income increases roughly linearly over the next 14 years.

\footnotetext{
${ }^{15}$ It assumes 15\% pay upfront and then losses from student support are computed based on Table A4 in the Appendix.
} 


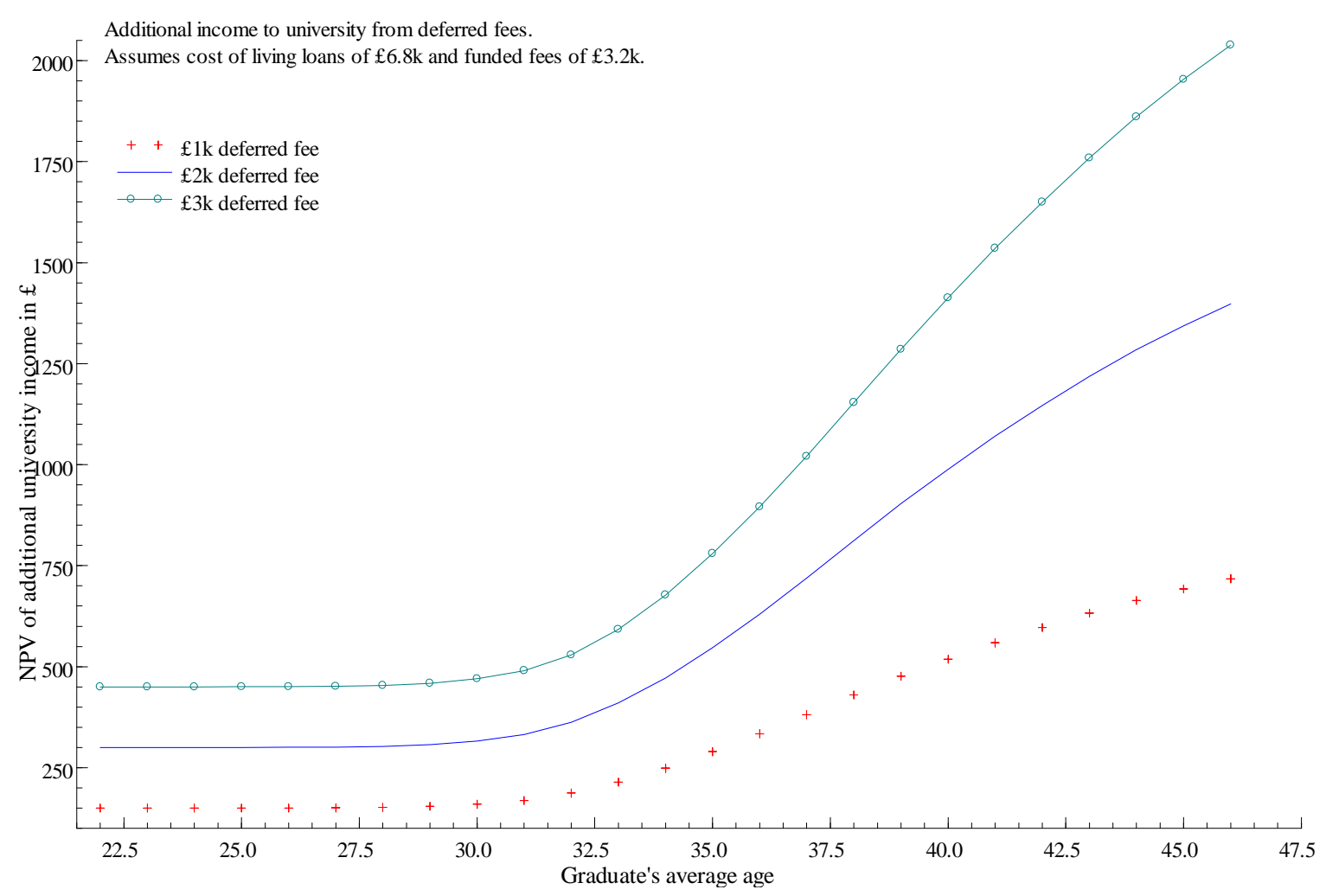

Figure 1. NPV of income to university from deferred fees for three different annual levels of deferred fees: $£ 1 k, £ 2 k$ and $£ 3 k$.

\subsubsection{Who would pay deferred fees to universities?}

The right hand side of Table 3 shows various quantiles ${ }^{16}$ of the average forecasted earnings of these graduates from age 22 to 46 . The $50 \%$ quantile average earnings for men is $£ 48.9 \mathrm{k}$ a year while for women it is $f 32.4 k$. It shows that deferred fees typically are paid by those with average real earnings above $f 40 \mathrm{k}$. This covers $70 \%$ of men and $30 \%$ of women. These averages are over the ages 22 to 47, but in reality almost all payments are made from ages 31 upwards when earnings are higher than during the early years of the graduate's career. All lower earners pay nothing.

\begin{tabular}{|c|c|c|c|c|c|c|}
\hline \multirow[b]{2}{*}{ Quantile } & \multicolumn{3}{|c|}{ Payment of deferred fee } & \multicolumn{3}{|c|}{$\begin{array}{c}\text { Forecasted average real earnings } \\
\text { for graduates aged } 22-46\end{array}$} \\
\hline & All & Male & Female & All & Male & Female \\
\hline $1 \%$ & $0.0 \mathrm{k}$ & $0.0 \mathrm{k}$ & $0.0 \mathrm{k}$ & $6.4 \mathrm{k}$ & $14.5 \mathrm{k}$ & $4.6 \mathrm{k}$ \\
\hline $5 \%$ & $0.0 \mathrm{k}$ & $0.0 \mathrm{k}$ & $0.0 \mathrm{k}$ & $13.6 \mathrm{k}$ & $24.4 k$ & $10.4 \mathrm{k}$ \\
\hline $10 \%$ & $0.0 \mathrm{k}$ & $0.0 \mathrm{k}$ & $0.0 \mathrm{k}$ & $18.7 \mathrm{k}$ & $28.9 \mathrm{k}$ & $14.2 \mathrm{k}$ \\
\hline $20 \%$ & $0.0 \mathrm{k}$ & $1.6 \mathrm{k}$ & $0.0 \mathrm{k}$ & $25.9 k$ & $35.1 \mathrm{k}$ & $19.6 \mathrm{k}$ \\
\hline $30 \%$ & $0.0 \mathrm{k}$ & $2.9 \mathrm{k}$ & $0.0 \mathrm{k}$ & $31.1 \mathrm{k}$ & $39.8 \mathrm{k}$ & $24.2 \mathrm{k}$ \\
\hline $50 \%$ & $2.98 \mathrm{k}$ & $3.0 k$ & $0.5 \mathrm{k}$ & $40.2 \mathrm{k}$ & $48.9 \mathrm{k}$ & $32.4 \mathrm{k}$ \\
\hline $70 \%$ & $3.0 \mathrm{k}$ & 3.0k & $2.9 \mathrm{k}$ & $50.0 \mathrm{k}$ & $59.6 k$ & $40.7 k$ \\
\hline $80 \%$ & $3.0 k$ & $3.0 \mathrm{k}$ & $3.0 k$ & $57.0 \mathrm{k}$ & $67.3 \mathrm{k}$ & $45.3 \mathrm{k}$ \\
\hline $90 \%$ & $3.0 k$ & $3.0 k$ & $3.0 \mathrm{k}$ & $68.6 \mathrm{k}$ & $78.9 \mathrm{k}$ & $52.2 \mathrm{k}$ \\
\hline $95 \%$ & $3.0 \mathrm{k}$ & $3.0 \mathrm{k}$ & $3.0 \mathrm{k}$ & $79.5 \mathrm{k}$ & $89.1 \mathrm{k}$ & $58.4 \mathrm{k}$ \\
\hline $99 \%$ & $3.0 \mathrm{k}$ & $3.0 \mathrm{k}$ & $3.0 \mathrm{k}$ & $100.7 k$ & $108.3 \mathrm{k}$ & $70.9 \mathrm{k}$ \\
\hline
\end{tabular}

Table 3. Who eventually pays deferred fees at the level of $f 3 k$ per year assuming the cost of living support is $f 6.8 \mathrm{k}$ ? Based on forecasted real earnings paths from the age 22-46 we compute the quantiles of the average earnings for men and women graduates. This is on the right hand side of the table. On the left hand side are the corresponding levels of payments of deferred fees. It shows more deferred fees are paid by men and both men and women typically pay deferred fees if their average real incomes are above $£ 40 k$.

\footnotetext{
${ }^{16}$ Recall the $1 \%$ quantile is the smallest amount which is bigger than $1 \%$ of the data.
} 


\subsubsection{Bringing the cash flow forward}

\section{The challenge}

As Figure 1 shows deferred fees deliver (i) some upfront payments by wealthier parents, (ii) little extra income over the subsequent 10 years, (iii) a new income flow 10-25 years after the graduates finish at university as they prosper. These fees are highly progressive, only paid by the wealthier upfront or better-off graduates. However, it would be attractive if universities could opt to unlock the income flow under (iii) so some of it could be spent now on the current students (who as graduates will collectively pay the bill), allowing the quality of the education to potentially rise immediately. What options are available to bring the cash flow under (iii) forward?

As the Student Loan Company collects the money through time from graduates, an annual cheque will be sent to the university with the realised deferred fees from its graduates. I will call this the cohort's payment. The obvious approach is to sell this stream of 25 years of the cohort's annual payments to a bank or insurance company, receiving in return an upfront capital payment which can be spent on education immediately. Students and graduates are entirely unaffected by who owns this stream, they just deal with the SLC. This approach is called securitisation and would be an enormous mistake for the reasons discussed in the Appendix: in short, I argue that this is likely to deliver a low and volatile price.

In principle, the government might buy the flow of the cohort's annual payments from the university. This would increase the size of the government's loan book but not increase its RAB or deficit if the price was right. For universities with weak balance sheets this approach may be attractive and this would harvests many of the advantages of deferred fees. Unfortunately the size of the state's loan book is itself a problem at the moment due to the UK's fiscal position. So this approach itself would need to be rationed if used at all, although it may be useful in the long-term.

\section{Why annuitisation should work}

The most attractive route is for the university to carry out the financing themselves via annuitisation so the state is not involved at all. The university would sell a cash flow which is a conservative estimate of the cohort's payments ${ }^{17}$. This avoids the state's loan book entirely. The obvious buyers would be banks or insurance companies. This is most easily explained through an example.

Recall Figure 1 , focusing on the $f 3 k$ deferred fee level. The university receives about $15 \%$ of the deferred fees upfront, which is $£ 450$. In addition it will receive 25 annual payments whose NPV after 25 years is around $f 1.5 \mathrm{k}$, but where the first 10 years are almost entirely barren. After the age of 32 the payments are well approximated by a straightline with about 12 payments of $£ 125$ a year.

My preferred approach then is to sell a conservative estimate of this cash flow, say $£ 100$ NPV a year for the last 12 years of the 25 year period. In cash terms this sale would be in the $\mathrm{j}$-th year after graduation $100(1+G C B+\text { inflation })^{j}$, for $\mathrm{j}=14,15, \ldots, 25$, where inflation is 0.02 and $\mathrm{GCB}=0.022$, which is the government's cost of borrowing in real terms ${ }^{18}$.

\footnotetext{
${ }^{17}$ In practice a number of universities might just borrow the money from a bank on a long maturity loan and pay this liability off through time as the cohort's payments arrive.

${ }^{18}$ It is tempting to sell an index-linked cash flow as the cohort's payments should be roughly indexed-linked. However, this would mean the university would be exposed to an unbounded liability, which is unattractive.
} 
The university would have to fund each year the difference between the cohort's payments (income) and this sold cash flow (cost) from its balance sheet. If the payments were high compared to what was sold then this would add to the balance sheet of the university in future years, if they were low, then the university would have to supplement the cash flow from other income. By selling a conservative cash flow I would hope most of these adjustments would be beneficial.

Financially this is the same as selling a bond. How much would it be worth? Write $\mathrm{R}$ to denote its value, then it should be roughly worth $R=100 \sum_{j=14}^{25} \theta^{j}$, where $\theta=(1+G C B+$ inflation $) /$ $(1+r)$, where $r$ is the interest rate the university can borrow at over a 25 year period ${ }^{19}$. For the government $r=0.0461^{20}$ on $7 / 4 / 10$, which roughly would be the number a university with a AAA credit rating can borrow at. Then $\theta=0.9963$, so $R=100 \times 11.16=£ 1,116$. This is less than $£ 1.2 \mathrm{k}$ simply due to the government cost of borrowing being slightly low at the moment, for the government's cost of borrowing is close to the long-run interest rate on gilts. The effect of the interest rate can be seen from the following. If $r=0.0561$ or $r=0.0661$, delivers $\theta=0.9866$ or 0.9774 and so $R$ is $f 923$ or $£ 707$. Universities with strong credit ratings, close to AAA, will obtain a rate which is close to $0.0461^{21}$ and can carry out this financing as efficiently as the government ${ }^{22}$.

An important aspect of this bond sale is that the value of the bond is much lower than the face value of the deferred fees $f 3 \mathrm{k}$. The sale would be worth roughly $f 1.1 \mathrm{k}$. The reason for this is (i) many graduates will not be able to afford to pay the deferred fees, (ii) some students will pay upfront, (iii) I am suggesting selling a conservative estimate of the cash flow.

\subsubsection{Subject-specific deferred fee at a single institution}

Universities currently receive very different amounts of income for teaching different subjects, due to HEFCE's subject premiums. However, UK and other-EU graduates face the same funded fee whatever and wherever they study. Under deferred fees this would change, with the level of fees varying between institutions. A different question is whether it should vary within institutions, with some courses having higher deferred fees than others.

In my view the main difficulty with course fee variability is that this makes the system more complicated to the student when they are making up their mind what and where to study. Most US universities have equal fees whatever major the students opt for. This is partly because their liberal arts approach admits students to an institution, not a course, and only requires them to choose a major after one or two years of study, and then allows them to change majors easily. The UK system is more subject focused, which opens up this question anew.

I will use the following nomenclature in this discussion: Deferred fees = standard deferred fee + subject-specific deferred fee. Each element would be set by the university.

\footnotetext{
${ }^{19} R$ is a "finite geometric procession" so it is well known it can be reexpressed as $R=100\left(\theta^{14}-\theta^{26}\right) /(1-\theta)$.

${ }^{20}$ Source FT, April 7, 2010 computed using Treasury Bond 4.5\% redemption in 2036.

${ }^{21}$ Corporate bond spreads between a bond and a AAA rated bond, using the FTSE Sterling Corporate Bond Yields Index, on 12/4/10 were AA: 0.217. A: 0.326. BBB: 0.61 .

${ }^{22}$ Standard \& Poor's have rated King's College, London and Lancaster University, which have issued bonds in the past, AA. Sheffield and Nottingham are currently rated AA-. Cambridge University have announced plans to sell a bond worth up to $£ 300 \mathrm{M}$ but I don't know of their credit rating. St Peter's College, Oxford was rated AAA by Fitch. Selling bonds is common place amongst leading US universities. In 2006 the Wellcome Trust listed a 30 year bond and raised $f 550 \mathrm{M}$. More recently it raised $£ 275 \mathrm{M}$ through a 12 year issue. The Trust has an AAA rating, which is the same as that of the government. It is useful to note that the Wellcome Trust typically tries to sell bonds: (i) to the same value as its cash position, so that it is "fully invested", (ii) have the coupons on its bond covered by the rental income from its residential portfolio which is regarded as a very safe covenant. These are sensible conservative rules for a charity to use and should certainly be thought through by any university going down this route.
} 
There is an argument that non-professional courses, such as physics and engineering, which receive HEFCE subject premiums, should have a zero subject-specific deferred fee. The reason is that the state is paying extra funded fees for these course - an extra scholarship to students. Thus if better off graduates pay more back because they studied this subject, the money should naturally go back to the state in the first instance.

Perhaps the strongest case for subject-specific deferred fees are courses which do not attract HEFCE premiums but are related to highly paid professional pathways and are massively oversubscribed. The leading examples would be law and management courses.

\section{Financial summary.}

Charge close to the government's cost of borrowing on financial support.

- Makes a significant financial difference to the long-run position of higher education sector.

- Does not help in the short-term due to the way the public accounts work.

- Poorer graduates would be entirely protected by this reform.

Deferred fees. They:

- Are estimated to yield about $2 / 3$ of their face value to an average university.

- Graduates who pay will typically be on higher rates of income tax and start paying after their early 30s and pay them off after about 3 more years (relative to when they pay off their standard financial support).

- Graduates with low earnings pay nothing.

- $3 / 4$ of their long-run value will take up to 25 years to be collected.

- This 25 year cash flow can be capitalised by working with a bank.

- Allow much of this income to be spent now improving the quality of higher education.

- Universities with poor credit ratings could work with the state to capitalise the value at no short or long-term fiscal cost.

In the long-run move to making the cost of living support simpler by replacing grants and bursaries with a higher level of student financial support. This either

- Improves the short-term fiscal position, or

- Allows the number of students to grow substantially.

\section{Part-time students}

Part-time and continuing education is becoming increasingly important in the UK as the population lives longer and individuals need to refresh or reinvest in their professional skills or develop new interests outside their workplace. Educational Savings Accounts could be used to pay for tuition fees for part-time or further education. Further, part-time students can be helped by making it easier to use salary sacrifice schemes to pay for their tuition costs. If their salaries are low then it may make sense to allow access to the efficient student financial support system discussed above, but solely 
for funding tuition costs. As there are no living costs to repay it is likely to that this kind of funding will be repaid and quite quickly and so be relatively cheap to provide.

\section{Conclusion}

I have argued for a simpler, fairer, more fiscally responsible and flexible form of university funding and student support. This system is designed to encourage a diverse higher education sector where high quality provision can flourish. The main points of the new system are:

1. Make student financial support available to cover all tuition and a modest cost of living.

2. Allow graduates to repay according to earnings with protection for poorer graduates.

3. Call HEFCE grants "scholarships" and make students aware of their value.

4. Cap the level of funded fees plus HEFCE grant at the current level.

5. Allow universities to charge deferred fees.

a. When they are paid the money goes to the student's university not to the state. These fees have no fiscal implications.

b. Bring some of the cash flow from deferred fees forward by working with a bank.

6. In the long-run move to making the cost of living support simpler by

a. Providing more realistic cost of living support for all students.

b. Removing means-tested university bursaries for cost of living expenses.

c. Removing means-tested grants to students provided by the state.

This builds on England's higher education structure. The changes are simple to implement. It would set up a stable funding structure for our universities and our students.

\section{References and additional reading}

Barr, N. (2004) "Higher education funding," Oxford Review of Economic Policy, 20, 264-283

Barr, N. \& A. Johnston (2010) "Interest subsidies on student loans: a better class of drain," Discussion paper 114, London School of Economics: Centre for the Economics of Education, March 2010, http://cee.Ise.ac.uk/cee\%20dps/ceedp114.pdf.

Bekhradnia, B. and W. Massy (2009) “Vouchers as a mechanism for funding higher education," HEPI.

Chowdry, H., C. Crawford, L. Dearden, A. Goodman and A. Vignoles (2010) "Widening participation in higher education: analysis using linked administrative data," Institute of Fiscal Studies, working paper W10/04.

Dearden, L., E. Fitzsimons, A. Goodman \& G. Kaplan (2008) “Higher Education Funding Reforms in England: the distributional effects \& the shifting balance of costs", Economic Journal 118, F100-125.

Dearden, L, A. Goodman, G. Kaplan and G. Wyness (2010) “Future arrangements for funding higher education," www.ifs.org.uk/comms/comm115.pdf

Institute of Fiscal Studies (2010) "Reforms to tuition fees and student support had no overall impact on the number of 18 or 19 year olds attending university in England," press release, $28^{\text {th }}$ January, 2010.

Keys, B.J., T. Mukherjee, A. Seru and V. Vig (2010) "Did securitization lead to lax screening? Evidence from subprime loans," Quarterly Journal of Economics, 125, 307-362.

Laidlaw, S. (2009) "Stronger Together: business and universities in turbulent times," report of the CBI's Task Force on Higher Education. highereducation.cbi.org.uk/uploaded/CBI HE taskforce report.pdf 
National Union of Students (2009) "Broke and broken: a critique of the higher education funding system," www.nus.org.uk/PageFiles/3115/Brokeandbroken.pdf

National Union of Students (2009b) “NUS Press Pack 2009-2010. Higher Education Student Finance.”

National Union of Students (2010) “Accommodation Costs Survey 2009/10,"

http://resource.nusonline.co.uk/media/resource/WEB SW NUS UNIPOL Microsoft\%20Word\%20-

\%20Accommodation Costs Survey 2010 FINAL.pdf

Office of Fair Access (2009) "Annual Report and Accounts," www.offa.org.uk/wp-

content/uploads/2009/08/090611-office-for-fair-access-annual-report.pdf

Shephard, N. (2010) "Submission to the review on Higher Education funding and student finance, $1^{\text {st }}$ call for evidence," www.oxford-man.ox.ac.uk/ nshephard/submissionto140110.pdf

\section{Structure of the Appendix}

A. Modelling of losses from student financial support.

B. What the UK should not do.

C. Deferred fees from different perspectives.

D. Directly responding to the evaluation criteria of the Browne Review. 


\section{A. Appendix: modelling of losses from student financial support}

\section{A1. The "data": simulated earnings paths}

Throughout this appendix I use a database of forecasted simulated earnings paths produced by Dearden et al (2008) for the 2006-2007 academic year for a cohort aged 22 in that year. Each individual path is a projected or forecasted earnings path of a graduate, as they age from 22 up to $46^{23}$. It is designed to look as similar to real earnings paths for individual graduates as possible.

The paths are built out of a model of waves of the British Household Panel Survey from 1991 to 2004 inclusive and the Labour Force Survey from 1993 to 2003. Underlying their paths is an assumption that average real earnings across the working population will increase by $2 \%$ per year in the future. An individual graduate's earnings will increase at a much faster rate than $2 \%$ per year on average because as they age their earnings should also grow as their career progresses. Economists call this the life-cycle effect. This is reflected in the paths: on average, they initially climb steeply.

There are 20,000 simulated paths, half of which are labelled as men. I am grateful to Alissa Goodman and Greg Kaplan for permission to use them, though they have no responsibility for how I have used them, adjusted them or for any mistakes I have made in the process ${ }^{24}$.

Individual earning paths allows us to model how much, and when, each individual will pay back some parts of their financial support. The individual payments can then be aggregated up to produce forecasts of how much and when graduates as a whole will pay. This allows us to forecast the net present value losses the state will face on student financial support. It also allows us to estimate the income universities would receive from deferred fees.

The above paths are now slightly dated and so I reset them to start in the 2009-2010 academic year. I did this by adjusting the original paths by

- Uplifting all points on each path by multiplying by the ratio of the retail prices index in $2 / 2010$ (219.2) to the RPI in 12/2006 (202.7).

- Uplifting all by multiplying by $1.02^{3}$ to account for 3 years of real earnings growth of roughly $2 \%$ per year.

Taken together these two adjustments have an important effect, raising all paths by around $15 \%$ of their original value ${ }^{25}$. This materially affects the fiscal losses from student support.

To get used to this data it is helpful to look at Table 3 which gives some quantiles of early to mid average earnings over the ages 22 to 46 for the two genders. It shows the well-known feature that these earnings tend to be higher for men.

\footnotetext{
${ }^{23}$ It is a sample from the forecast joint distribution of annual earnings of an individual graduate as they age starting off at 22 in $2006-2007$ and continuing for 25 years, given knowledge of the gender of the graduate. Hence this is a 25 dimensional conditional random variable. ${ }^{24}$ Dearden, Goodman, Kaplan and Wyness (2010) also reported updated methods for simulating earnings paths. I do not have access to this updated database, although some of their results on estimated losses on various forms of student support seem roughly similar to those given here. See also the work of Barr and Johnston (2010) for further ideas about using these earning profiles.

${ }^{25}$ I have made no adjustments for the 2008-2009 recession where national income fell by around $5 \%$ in terms of UK sterling. The reason for this is that what matters in our analysis is long-run earning. The corresponding devaluation in sterling should mean the economy recovers from this shock in terms of domestic earnings, although valued in terms of dollar equivalent the impact may be permanent.
} 


\section{A2. Analysis of the current set-up}

\section{A2.1 Assumptions about the current set-up}

Here I spell out the assumptions behind each of the calculations reported in the paper.

\section{Assumptions for the current set-up}

Facts

- Government cost of borrowing is $2.2 \%$ real, which is used to calculate the net present value of any future payments by graduates.

- Payments are $9 \%$ of earnings over the threshold of $f 15 \mathrm{k}$. This threshold is assumed to be indexed by the retail prices index.

- The interest rate on student financial support is currently $0 \%$ real. The role of the interest rate is solely to determine when graduates are judged to have repaid their student support.

- Outstanding student financial support is forgiven after 25 years.

\section{Working assumptions}

- The current maximum living cost loan all students can draw down is $£ 3.6 \mathrm{k}$ and it is $£ 3.2 \mathrm{k}$ for fees. Thus the maximum financial support per student is around $f 6.8 \mathrm{k}$ per year.

- We assume each course lasts for 3 years.

- We assume no students partially pay upfront: evidence is that if students take out loans, then over $98 \%$ of them take out the full amount available. Thus we assume the average aggregate support for those not paying upfront is $£ 20.4 \mathrm{k}$ per student over 3 years. This is in line with Barr and Johnston (2010).

- Roughly $15 \%$ of students pay fees and maintenance upfront through resources given to them by, for example, their parents.

- Bursaries and scholarships play no role in this Appendix which focuses on the cost of providing the student financial support.

Taken together this means across the student population we have two groups: (i) $15 \%$ have no liabilities as they pay upfront, (ii) $85 \%$ have received $f 20.4 \mathrm{k}$ of student finance and they may repay this if they become better-off as graduates.

\section{A2.1. Who pays what now?}

Each individual path yields a path of annual payments to reimburse the state for the student's financial support. Of the $85 \%$ who take out the support, how much do they pay back and who pays it back? Table A1a answer this in the following way.

First it computes the average real earnings through the ages 22-46 of each individual and sorts them three times: for all graduates, for all male graduates and for all female graduates. So the bottom $1 \%$ quantile of earners is forecast to receive $f 6.4 \mathrm{k}$ real a year on average over this 25 year period, while for men this is $£ 14.5 k$ and for women this is $£ 4.6 k$. The much lower figure for women is due to a significant percentage of women not working for some of this period due to childcare choices. In 
contrast the $99^{\text {th }}$ quantile of earners receive $f 100.7 \mathrm{k}$ a year. That is $1 \%$ of the graduates earn at least $£ 100.7 \mathrm{k}$ a year on average over this 25 year period.

Having computed the average earners for these quantiles, we can ask how much do graduates in the lowest $1 \%$ quantile pay for their financial support of $£ 6.8 \mathrm{k}$ a year. The answer is $£ 0.9 \mathrm{k}$ a year, so the remaining $f 5.9 \mathrm{k}$ per year is forgiven. Hence those on low lifetime earnings pay back around $15 \%$ of the support they have received and are largely protected by the system.

The person on the $99 \%$ quantile of earnings pays back on $f 6.1 \mathrm{k}$, so the state picks up $f 0.7 \mathrm{k}$ per year of their support. This is not due to having any support forgiven, instead it is because of the low interest rate: $0 \%$ real, while it costs the state $2.2 \%$ real to provide this financing. This provides a subsidy to the highest earners in the country.

\begin{tabular}{|c|c|c|c|c|c|c|}
\hline \multirow[b]{2}{*}{ Quantile } & \multicolumn{3}{|c|}{$\begin{array}{c}\text { Lifetime payment for financial } \\
\text { support per year in today's } f \text { (NPV) } \\
\text { Now }\end{array}$} & \multicolumn{3}{|c|}{$\begin{array}{c}\text { Forecasted average real earnings } \\
\text { for graduates aged } 22-46\end{array}$} \\
\hline & All & Male & Female & All & Male & Female \\
\hline $1 \%$ & $0.9 k$ & $3.6 \mathrm{k}$ & $0.5 \mathrm{k}$ & $6.4 k$ & $14.5 \mathrm{k}$ & $4.6 \mathrm{k}$ \\
\hline $5 \%$ & $2.8 \mathrm{k}$ & $4.8 \mathrm{k}$ & $1.8 \mathrm{k}$ & $13.6 \mathrm{k}$ & $24.4 k$ & $10.4 \mathrm{k}$ \\
\hline $10 \%$ & $4.5 \mathrm{k}$ & $5.1 \mathrm{k}$ & $2.9 k$ & $18.7 k$ & $28.9 k$ & $14.2 \mathrm{k}$ \\
\hline $20 \%$ & $5.1 \mathrm{k}$ & $5.3 \mathrm{k}$ & $4.7 \mathrm{k}$ & $25.9 k$ & $35.1 \mathrm{k}$ & $19.6 \mathrm{k}$ \\
\hline $30 \%$ & $5.3 \mathrm{k}$ & $5.4 \mathrm{k}$ & $5.1 \mathrm{k}$ & $31.1 \mathrm{k}$ & $39.8 k$ & $24.2 \mathrm{k}$ \\
\hline $50 \%$ & $5.5 \mathrm{k}$ & $5.6 \mathrm{k}$ & $5.4 \mathrm{k}$ & $40.2 k$ & $48.9 k$ & $32.4 k$ \\
\hline $70 \%$ & $5.7 \mathrm{k}$ & $5.8 \mathrm{k}$ & $5.6 \mathrm{k}$ & $50.0 \mathrm{k}$ & $59.6 \mathrm{k}$ & $40.7 \mathrm{k}$ \\
\hline $80 \%$ & $5.8 \mathrm{k}$ & $5.9 \mathrm{k}$ & $5.7 k$ & $57.0 \mathrm{k}$ & $67.3 \mathrm{k}$ & $45.3 k$ \\
\hline $90 \%$ & $5.9 \mathrm{k}$ & $6.0 \mathrm{k}$ & $5.8 \mathrm{k}$ & $68.6 \mathrm{k}$ & $78.9 k$ & $52.2 \mathrm{k}$ \\
\hline $95 \%$ & $6.0 \mathrm{k}$ & $6.0 \mathrm{k}$ & $5.9 \mathrm{k}$ & $79.5 \mathrm{k}$ & $89.1 k$ & $58.4 k$ \\
\hline $99 \%$ & $6.1 \mathrm{k}$ & $6.2 \mathrm{k}$ & $6.1 \mathrm{k}$ & $100.7 \mathrm{k}$ & $108.3 \mathrm{k}$ & $70.9 \mathrm{k}$ \\
\hline
\end{tabular}

Table A1a. How much of the financial support of $f 6.8 \mathrm{k}$ taken out by the students is paid back? Based on forecasted real earnings paths from the age 22-46, we report the quantiles of the average earnings for men and women on the right hand side of the table.

The same method can be used to look inside some of these figures. Due to government rules, payments by graduates first pay towards cost of living support. Once this is paid off, payments go towards tuition. So we can ask on average how much of these items are repaid, or more interestingly, not repaid. Table A2a contains an estimate of this, averaged over the population. It show a loss of $£ 0.6 \mathrm{k}$ on cost of living per year per student, $£ 0.9 \mathrm{k}$ on fees and $£ 1.5 \mathrm{k}$ overall.

\begin{tabular}{|r|r|}
\hline Financial support & $\begin{array}{r}\text { Average loss to the state from student financial } \\
\text { support in today's } f(N P V)\end{array}$ \\
\hline & Now \\
\hline Cost of living & 602 \\
Tuition & 943 \\
\hline Total & 1,545 \\
\hline
\end{tabular}

Table A2a. Losses to the state of the current setup, per year, per student, for the $85 \%$ of students who take out the student financial support package. Source: author's calculations using the code deferred_analysis.ox written by the author. 


\section{A4. Removing the rate subsidy}

\section{Reform 1. Removing the rate subsidy}

- Charge an interest rate which is the Government's cost of borrowing, which is currently $2.2 \%$ real.

We make a single change to the current set-up. The results are given in Tables $A 1 b$ and $A 2 b . A 1 b$ looks at the distributional implications of the change and shows better-off graduates making full repayments of their student financial support. Roughly $95 \%$ of men make full repayments while $70 \%$ of women do. The poorest graduates are not affected by this change. In terms of average lifetime earnings, then those whose average is above $\mathrm{f} 25 \mathrm{k}$ a year make full repayments. Those below this number receive support.

The system could be made more progressive by matching the increase in interest rate by a reduction in the payment rate, say down to $7 \%$ or $8 \%$. Overall this would be a fiscally cheaper and fairer system than the current one. This combination of reforms was first suggested by Shephard (2010) and has been subsequently analysed in detailed by Dearden, Goodman, Kaplan and Wyness (2010). To keep the focus of this note on deferred fees I am not going to discuss this option again here.

\begin{tabular}{|c|c|c|c|}
\hline \multirow[b]{2}{*}{ Quantile } & \multicolumn{3}{|c|}{$\begin{array}{l}\text { Lifetime payment for financial support per } \\
\text { year in today’s } f k \text { (NPV) } \\
\text { Removing rate subsidy }\end{array}$} \\
\hline & All & Male & Female \\
\hline $1 \%$ & $0.9 \mathrm{k}$ & $3.6 \mathrm{k}$ & $0.5 \mathrm{k}$ \\
\hline $5 \%$ & $2.8 \mathrm{k}$ & $6.7 \mathrm{k}$ & $1.8 \mathrm{k}$ \\
\hline $10 \%$ & $4.7 \mathrm{k}$ & $6.8 \mathrm{k}$ & $2.9 \mathrm{k}$ \\
\hline $20 \%$ & $6.8 \mathrm{k}$ & $6.8 \mathrm{k}$ & $5.0 \mathrm{k}$ \\
\hline $30 \%$ & $6.8 \mathrm{k}$ & $6.8 \mathrm{k}$ & $6.8 \mathrm{k}$ \\
\hline $50 \%$ & $6.8 \mathrm{k}$ & $6.8 \mathrm{k}$ & $6.8 \mathrm{k}$ \\
\hline $70 \%$ & $6.8 \mathrm{k}$ & $6.8 \mathrm{k}$ & $6.8 \mathrm{k}$ \\
\hline $80 \%$ & $6.8 \mathrm{k}$ & $6.8 \mathrm{k}$ & $6.8 \mathrm{k}$ \\
\hline $90 \%$ & $6.8 \mathrm{k}$ & $6.8 \mathrm{k}$ & $6.8 \mathrm{k}$ \\
\hline $95 \%$ & $6.8 \mathrm{k}$ & $6.8 \mathrm{k}$ & $6.8 \mathrm{k}$ \\
\hline $99 \%$ & $6.8 \mathrm{k}$ & $6.8 \mathrm{k}$ & $6.8 \mathrm{k}$ \\
\hline
\end{tabular}

Table A1b. How much of the financial support of $£ 6.8 \mathrm{k}$ taken out by students is paid back if the interest rate subsidy is removed? Otherwise same as Table Ala.

The overall results are given in Table A2b, which shows the state's losses fall very considerably, saving the higher education budget a great deal in the long run, although it does not significantly help in the short-run due to the way the public accounts work.

\begin{tabular}{|r|r|}
\hline Financial support & $\begin{array}{r}\text { Average loss to the state from student } \\
\text { financial support in today's } \mathrm{f} \text { (NPV) }\end{array}$ \\
\hline & Removing rate subsidy \\
\hline Cost of living & 114 \\
\hline Tuition & 378 \\
\hline Total & 492 \\
\hline
\end{tabular}

Table A2b. Source: author's calculations using the code deferred_analysis.ox written by the author. 


\section{A5. Increasing the level of student support from the state}

\section{Reform 2. Increasing support from the state}

- Charge an interest rate which is the Government's cost of borrowing, which is currently $2.2 \%$ real.

- Increase the state's student financial support from $£ 6.8 \mathrm{k}$ to $f 10 \mathrm{k}$. Can be used to improve cost of living support, phase out grants, or increase funded fees.

Table A2c contains the results if the level of student financial support goes up to $f 10 k$.

\begin{tabular}{|r|r|}
\hline Financial support & $\begin{array}{r}\text { Average loss to the state from student } \\
\text { financial support in today's } £ \text { (NPV) }\end{array}$ \\
\hline Removing rate subsidy \& $£ 10 k$ support \\
\hline Cost of living & 492 \\
Tuition & 762 \\
\hline Total & 1,254 \\
\hline
\end{tabular}

Table A2c. Source: author's calculations using the code deferred_analysis.ox written by the author.

Table A3 shows different levels of support and the resulting losses to the state before and after the removal of the rate subsidy. It shows a substantial reduction in losses caused by increasing the interest rate, but the resulting savings moderating as the level of financial support increases.

\begin{tabular}{|c|c|c|}
\hline & \multicolumn{2}{|c|}{ Loss to the state per year } \\
\hline Financial support & Current system & $\begin{array}{l}\text { Removing the } \\
\text { rate subsidy }\end{array}$ \\
\hline Now: 6,800 & 1,545 & 492 \\
\hline 8,000 & 1,973 & 727 \\
\hline 8,666 & 2,228 & 883 \\
\hline 9,333 & 2,495 & 1,059 \\
\hline 10,000 & 2,775 & 1,254 \\
\hline 10,666 & 3,065 & 1,471 \\
\hline 11,333 & 3,368 & 1,707 \\
\hline 12,000 & 3,682 & 1,962 \\
\hline 12,666 & 4,008 & 2,239 \\
\hline 13,333 & 4,345 & 2,537 \\
\hline 14,000 & 4,693 & 2,856 \\
\hline
\end{tabular}

Table A3. Shows total losses for various levels of annual student financial support.

\section{A6. Income from deferred fees}

\section{Reform 3. Allowing deferred fees}

- Charge an interest rate which is the Government's cost of borrowing, which is currently $2.2 \%$ real.

- Once cost of living and funded fees are repaid to the state, the graduate pays the university the deferred fees if they can afford them. If the graduate is unable to pay them, using the usual student financial support system, then they are forgiven. Hence the university takes the risk for these kind of fees.

- I assume the university's graduates are a random selection of the UK's graduates. Hence the calculation is for a typical university. 
Table A4 presents the amount of forgiveness of deferred fees by its graduates who did not pay upfront. The difference between the face value of the deferred fee and this level of forgiveness is the new income source for the university. The Table reports results for two different levels of cost of living support. Clearly if this is low then the university will receive more additional income from their deferred fees.

\begin{tabular}{|r|r|r|}
\hline & \multicolumn{2}{|c|}{ Forgiving of deferred fees } \\
\hline Level of deferred fee & State support: & State support: \\
\cline { 1 - 2 } & $\underline{6,800}$ & $\underline{10,000}$ \\
\hline 1,000 & 192 & 331 \\
\hline 2,000 & 425 & 707 \\
\cline { 1 - 1 } 3,000 & 701 & 1,130 \\
\cline { 1 - 1 } 4,000 & 1,025 & 1,601 \\
\cline { 1 - 1 } 5,000 & 1,391 & 2,116 \\
\cline { 1 - 1 } 6,000 & 1,805 & 2,676 \\
\cline { 1 - 1 } 7,000 & 2,266 & 3,278 \\
\cline { 1 - 1 } 8,000 & 2,772 & 3,919 \\
\cline { 1 - 1 } 9,000 & 3,323 & 4,596 \\
\hline
\end{tabular}

Table A4. Shows how much deferred fees are expected to be forgiven for different levels of deferred fee and different amounts of state support. Source: author's calculations using the code deferred_analysis.ox written by the author. 


\section{B. Appendix. What the UK should not do}

\section{B.1 Substantially increase the fee cap using the current system}

Under the current system there is a cap on funded fees and no deferred fees. If the current cap on funded fees was to increase then (almost all) universities will increase their fees to the cap, as they will get all of the funded fees from the state even if the resulting graduates cannot afford to pay them. This is because the state guarantees the income up to the cap. Hence the current system incentivises universities to set high funded fees and removes price variability. This is a particular problem at the moment when there is a shortage of university places, so there will be always be students willing to sign up to universities even if the funded fee level is high.

\section{B.2 Means testing upfront payments with exclusion}

US private universities (and some UK private schools) often provide access for the less better-off by having means tested entry. How does this work?

The idea is that the university would require some upfront payments by all students (most would also need to take out loans) except those who are from less better-off families, assessed through a university specific means test. If the family disagrees with the university about what is affordable as the family's contribution they are excluded as they cannot front the money. This is common practice at the main private US universities, although not much discussed in the UK.

To illuminate this it is useful to tell the story of two people I have discussed this issue with while writing this note.

Story 1. She was offered a place at Harvard, but the family was required to make a substantial contribution to the cost of the fees and living costs. The father of the prospective student thought the family could not afford it so said the child could not go. Eventually the mother persuaded the father they could take out a large bank loan to pay and the student was able to go.

Story 2. This national merit scholar wished to go to a major research university such as MIT. Her very wealthy parents did not want her to focus on science, which was the preference of their child, and said they would not pay for the cost of the research university. Due to means testing, where the university expected her to pay upfront, she could only afford to do what her parents wanted her to do. The student eventually went to a small liberal arts college, the preference of the parents.

I think this is unacceptable, for UK universities should be free at the point of use so students can follow their dreams.

This is a very important point. Means testing with exclusion is a strong weapon used by US universities to increase the rate of upfront payment by the better-off. My proposal would mean this is unavailable to UK universities. They will have to rely on income contingent payments by better-off graduates and voluntary upfront payments.

\section{B.3 Discounts for upfront payment}

To reduce the existing losses on the student loan book caused by the low interest rate some have suggested offering a discount to graduates who pay early. This has some merits for existing student 
financial support, in effect clearing out the current inefficient system ${ }^{26}$. But all new student financial support should have an interest rate which is the government cost of borrowing (or just above it) and giving a discount for such support would be in aggregate costly, pointless and give a subsidy available solely to the better-off so is regressive. Further, around $15 \%$ of students currently pay upfront and this rate should increase with a higher interest rate and providing a discount for these people just leads to financial (deadweight) loss to the higher education budget.

\section{B.4 Graduate taxes}

Various groups, including the Nation Union of Students (2009), have proposed funding higher education using graduate taxes. They argue for different mechanisms, but the general idea is as follows: all UK domiciled graduates who went to a UK university to study as an undergraduate would pay an additional income tax for a finite time. An example of this is $5 \%$ of earnings for 15 years.

The main motivations for graduates taxes is that (i) they are simple to understand, (ii) those who had large private benefit from going to university will pay more which seems fair and their payments are related to affordability, (iii) there no sticker price (ex-ante) competition between universities and so prospective students can make their decision on what is the best course simply on the basis of its educational qualities (rather than also taking into account its value for money).

The low payment rate is possible as some graduates will pay a great deal more for their education than currently, as their graduate tax liability is unlimited.

Graduate taxes are really the same as the current system except:

- Fees are literally infinitely large as they cannot be paid off, e.g. a graduate earns $f 10 \mathrm{M}$ a year, she would pay f500k a year to the state for her education.

- Education at an English Universities would be free to French students, but not the English who would pay for both their own high education and those of the French (under EU law it is not possible to levy income taxes on the residents of other countries, but they can be charged for services).

- There is no financial reward to universities for providing high quality education.

- All current spending may appear on the PSBR (it is complicated to know for sure), currently only the losses on student financial support appear on the RAB.

- There is no role for philanthropy or sponsorship.

- There is no role for upfront payment by better-off parents, so making the system around $15 \%$ more expensive to run as this current contribution would be lost.

- It is unclear if the money raised will be given to universities, or just taken as a general tax and spent on something else such as the NHS.

I conclude from this that graduate taxes are unjust and inefficient.

\section{B.5 Varying fees for teaching via quality kite marks}

One approach is to build a national administrative structure which rates the quality of the education provided by each particular course at each university. These assessments can then drive a quality

\footnotetext{
${ }^{26}$ As far as I can see from the way the public accounts work if graduates do pay-off the low interest rate loans with a discount, then the losses now recorded on the RAB would immediately move over to the current PSBR. This could be challenging to handle in the short run.
} 
kite marked system, which in turn could deliver varying prices according to this. In some sense this matches the research assessment exercise, which judges the quality of research as a method for distributing some research income to universities.

Of course it is easier to assess a published academic paper than a whole course, so the burden on inspectors and the inspected would likely be quite high. Further, this would be a massive loss of autonomy of universities and enormously boost the state's control of universities. Finally, the job of inspection will not be a very attractive one and so it may be very hard to produce high quality assessments of cutting edge teaching. This would deflate innovation.

\section{B.6 Increasing length of payments}

A number of writers have argued to lengthen the usual 25 year payment period for student financial support as this reduces the number of graduates who fail to pay in full their fees or living costs. Unfortunately the people who fail to pay are the poorer graduates so they are the only ones asked to pay more by this reform. Hence this is regressive and should be avoided.

This policy change could, however, be made progressive by combining it with some other reforms. An example would be to reduce the payment rate down to $7 \%$, increase the interest rate to the government cost of borrowing (or slightly above it), forgiving payments at 30 years and increasing the threshold to say $£ 20 k$.

\section{B.7 Vouchers}

A number of writers have argued the UK should use vouchers to help fund higher education. This would involve individual students being given a voucher which can be used to pay for all or part of their fees at a university. This is analysed by, for example, Bekhradnia and Massy (2009).

The HEFCE teaching grant follows the student via an approximate formula funding scheme and so from an economic viewpoint already acts exactly like a voucher. However, the UK system of additional student financial support overcomes the usual problem of vouchers which is that liquidity constrained students (typically those from financially poorer backgrounds) are unable to afford places which cost more than the value of the voucher.

A problem with the current HEFCE teaching grant is that it is invisible to the student and so unappreciated that they are in effect all being given a very substantial scholarship. This is probably damaging both for access and for the perception amongst students more generally that they are being supported by the state and the system is fair. It would be better to label this grant a scholarship and tell students about it.

\section{B.8 Making students take out loans with a bank}

A number of authors have argued that a university could do a deal with a bank allowing all of its undergraduates to have an unsecured creditline. This type of arrangements are not uncommon for MBA courses and at undergraduate level at US universities. The students then pay the university its fees upfront with borrowed money. The repayments by students are not related to earnings but the size of the loan. The interest rate is typically quite high and the repayment period short. 
For example the HSBC-London Business School MBA loan is $2.75 \%$ above base rate (base rate is roughly the government's cost of borrowing), while they also charge a $1 \%$ arrangement fee and the repayment period is 7 years. The maximum borrowing is $f 50 \mathrm{k}^{27}$.

I do not favour this approach as there is no guarantee that the repayments are affordable as they are not related to earnings. Further, there is no protection for those graduates who have low earnings, say below $£ 15 k$. As a result this approach is likely to be highly damaging for access where young people from poorer backgrounds will be rationally concerned that they will have a chance that after higher education their earnings might not be high enough to pay off these loans and so they will be either bankrupted or left destitute.

\section{B.9 Deferred fees and securitisation}

A university with deferred fees could capitalise the income by selling the stream of 25 years of the cohort's annual payments to a bank or insurance company, receiving in return an upfront capital payment which can be spent on education immediately. Students and graduates are entirely unaffected by whom buys this stream, they just deal with the Student Loan Company.

This approach is called securitisation ${ }^{28}$. The bank takes on the knowledge that some graduates will fail to pay the face value of the deferred fee and that many will take a long time for the payments to arrive. Securitisation has the advantage to the university that all the income from the deferred fees would be realised in effect upfront, which is the traditional way it receives its tuition income. This kind of approach is most famous in the mortgage market, where bundles of mortgages loans are sold. This market had a massive setback in the late 2000 s and is still very weak.

In this context this approach is likely to perform poorly for the bank has no control over the collection mechanism or little in depth knowledge of the cohort $^{29}$ and so their investment will be perceived as being highly risky so yielding to the university a low and potentially volatile price (i.e. the price may change dramatically year on year).

\footnotetext{
27 www.london.edu/programmes/gettingaloan.html downloaded on 14th April, 2010.

${ }^{28}$ Keys et al (2010) have a recent discussion of securitisation and the US mortgage market and contains a discussion of the literature.

${ }^{29}$ Economists call this type of situation where the buyer knows much less about the good than the seller "asymmetric information."

Examples of this include user-car and life insurance sales. Such situations can lead to poor market outcomes unless great care is taken.
} 


\section{Appendix. Deferred fees from different perspectives}

\section{C.1 From a student's perspective}

The current total cost of going through an undergraduate education in the UK is about $f 30 k$. Around $70 \%$ of this is due to cost of living. Students can pay upfront. If they do not fund their education entirely upfront they can draw down financial support for their living costs and fees. The payment schedule is illustrated in Table C1.

\begin{tabular}{|r|r|r|r|r|}
\hline & & \multicolumn{2}{|c|}{ Monthly deductions } & \\
\cline { 1 - 4 } Name & Earnings & Income tax & $\underline{\text { NI }}$ & Monthly payments \\
\cline { 1 - 2 } Bill & $£ 14 \mathrm{k}$ & $£ 125$ & $£ 75$ & 0 \\
\cline { 1 - 2 } John & $£ 20 \mathrm{k}$ & $£ 225$ & $£ 130$ & $£ 37$ \\
\cline { 1 - 1 } Julie & $£ 30 \mathrm{k}$ & $£ 393$ & $£ 222$ & $£ 112$ \\
\cline { 1 - 1 } Jane & $£ 60 \mathrm{k}$ & $£ 1,160$ & $£ 363$ & $£ 337$ \\
\hline
\end{tabular}

Table C1. Author's calculations using http://listentotaxman.com. Monthly payments are $9 \%$ of earnings above $f 15 \mathrm{k}$.

These monthly payments continue to be paid until the earlier of: (i) the net present value of these payments reaches the amount of student financial support used, (ii) 25 years after graduating.

The level of monthly payments is not affected by the presence of deferred fees, removing cash bursaries or an increase in living cost support, it simply delays the time when everything is paid off. But this delay cannot extend the payment period beyond 25 years.

Given below is an example of a letter which would go to graduates each year detailing their financial position.

Dear Graduate:

This is your annual letter about the Student Financial Support you received at University of Exeter in 2000-2003 while you studied Mathematics.

The numbers given in this letter are on a per year basis, expressed in terms of their value in 2001 prices. This year the Student Support Company received $£ 1,506$ of payments from you towards your Student Financial Support. This is converted into 2001 figures as $C \times$ $£ 1,506 / 3$, where we divide by 3 as your course lasted 3 years. This year $C=0.667^{30}$ and it reflects the change in the level of prices from 2001 to 2010 and a modest real interest rate of $2.2 \%$. The result is a new contribution from you of $£ 335$ per year for your Student Financial Support.

I am pleased to say that alumni from your university have also made a contribution of $£ 127$ to forgiving some of your Student Financial Support. In 2001 prices, spread over three years, this is worth $f 28$ per year. You can find out more about who made these contributions by going to "website". Your university will write to you separately about this gift.

The current position of your Student Financial Support is given below. All numbers in this table are rounded to the nearest $f 1$. To summarise the cost per year of your education was

\footnotetext{
${ }^{30} \mathrm{RPI}$ in Jan 2010 was 217.9 , while in Jan 2002 it was 173.3 . Hence $\mathrm{C}=(173.3 / 217.9) / 1.022^{8}=0.667$. The 1.022 number is there as we apply a real interest rate of $2.2 \%$ per year, which is the cost to the government of providing the finance to you. If the interest rate was zero then $\mathrm{C}$ would be 0.795 .
} 
$£ 15,000$ and you received various scholarships which reduced this cost down to $£ 10,700$ per year. Your own payments since graduating, and some additional alumni gifts from your university, has now taken this figure down to $f 7,208$ per year over the three years.

\begin{tabular}{|c|c|c|c|c|c|}
\hline & & \multicolumn{4}{|c|}{ Student Financial Support per year } \\
\hline & $\begin{array}{r}\text { Full costs of } \\
\text { education } \\
\text { per year }\end{array}$ & At graduation & $1 / 4 / 09$ & $\begin{array}{r}\text { New } \\
\text { contributions } \\
\text { this year }\end{array}$ & $1 / 4 / 10$ \\
\hline Funded tuition costs ${ }^{31}$ & 6,700 & 6,700 & 6,700 & & 6,700 \\
\hline Deferred fee for university & 1,500 & 1,500 & 1,500 & & 1,500 \\
\hline Scholarship from the state & & $-3,500$ & $-3,500$ & & $-3,500$ \\
\hline Alumni gift & & -300 & -423 & -23 & -446 \\
\hline Cost of living & 6,800 & 6,800 & 6,800 & & 6,800 \\
\hline Business bursary & & -500 & -500 & & -500 \\
\hline Your contribution & & 0 & $-3,011$ & -335 & $-3,346$ \\
\hline Net Total & 15,000 & 10,700 & $\underline{7,566}$ & -358 & $\underline{7,208}$ \\
\hline
\end{tabular}

Recall your payments towards Student Financial Support are calculated as $9 \%$ of your earnings above $£ 15,000$ and are typically collected automatically from your salary in the same way as income tax and national insurance. These payments carry on until you have paid off the outstanding Student Financial Support. If you have any Student Financial Support outstanding in 2029, which is 25 years after you graduated, then this will be forgiven entirely and this will not affect your credit rating.

If you wish to make some voluntary early payments, either each month by direct debit or through a one-off lump payment, then this can be done via the website. This will not affect the value of your monthly payments (which as we said in the previous paragraph is determined by the level of your earnings), but it would speed the time when those payments would stop.

If you have any questions about this please visit "website" in the first instance.

Yours sincerely...

\section{2 From a university's perspective}

Unless a university charges less than the cap, it will get an upfront income of the HEFCE teaching grant plus funded fees of around $£ 3.2 \mathrm{k}$ plus subject premiums.

If they introduce deferred fees they may receive another source of income direct from their students or graduates. Some students will pay this upfront, others will pay it as better-off graduates over a 25 year time, after the cost of living and funded fees are repaid to the state. Some graduates will not have enough earnings and the university would forgive their liabilities after 25 years. Hence the university holds the risk associated with deferred fees and will not receive $100 \%$ NPV of the face value of the deferred fees when we average across the student population.

\footnotetext{
${ }^{31}$ Assumes HEFCE teaching grant of $£ 2.7 \times 1.3=£ 3.5 \mathrm{k}$ as this is a maths student and maths is in price group $\mathrm{C}$. This is relabelled a scholarship. Assume funded fees are $£ 3.2 \mathrm{k}$ and a deferred fee of $£ 1.5 \mathrm{k}$.
} 
Table C2a shows a numerical example of this, with the usual HEFCE teaching grant and funded fees totalling $f 6 k$, which is guaranteed to the university for a price group $D$ subject. I assume unfunded fees of $£ 3 k$ and $15 \%$ pay upfront. Of the $85 \%$ who take out Student Financial Support I assume for simplicity of illustration the university gets $30 \%$ or $75 \%$ NPV back. Overall then the unfunded fees raise $£ 1.21 \mathrm{k}$ or $£ 2.36 \mathrm{k}$ new income for the university using the face value of $£ 3 \mathrm{k}$. It costs the state nothing.

\begin{tabular}{|c|c|c|c|c|}
\hline \multirow[t]{2}{*}{ Source of payment } & \multicolumn{2}{|c|}{$\begin{array}{r}\text { Payment percentage of deferred } \\
\text { fees over } 25 \text { year period }\end{array}$} & \multicolumn{2}{|c|}{$\begin{array}{r}\text { Payment percentage of deferred } \\
\text { fees over } 25 \text { year period }\end{array}$} \\
\hline & $\underline{30 \%}$ & $\underline{75 \%}$ & $\underline{30 \%}$ & $\underline{75 \%}$ \\
\hline HEFCE grant \& funded fees & f6k & f6k & f6k & f6k \\
\hline $15 \%$ upfront payment of deferred fees & f0.45k & f0.45k & $£ 0.45 \mathrm{k}$ & $f 0.45 \mathrm{k}$ \\
\hline Philanthropic gift, $10 \%$ of deferred fees & & & f0.3k & $f 0.3 \mathrm{k}$ \\
\hline Deferred fees paid over 25 year period & $£ 0.76 \mathrm{k}$ & f1.91k & $£ 0.67 \mathrm{k}$ & f1.69k \\
\hline Total & $\underline{\underline{f 7.21 k}}$ & $\underline{\underline{f 8.36 k}}$ & $\underline{\underline{f 7.42 k}}$ & $\underline{\mathrm{f8.44k}}$ \\
\hline
\end{tabular}

Table C2a. Source: author's own calculations

\section{C.2.1 Philanthropic support or sponsorship}

The analysis becomes more attractive if there is a philanthropic contribution to student support, from alumni or industry through sponsorship, for example. I think the role of philanthropy should be to reduce the liabilities of students who do not pay upfront --- not to give them more cash for their living expenses. The next paragraph will show why this is a good idea. Table C2a also shows an example of this, reproducing the previous table but now where philanthropy pays $10 \%$ of the face value of the deferred fees. This reduces the amount graduates owe down to $75 \%$ of face value at both universities.

Clearly the students gain from philanthropy, but so do universities as there is less for them to forgive. Thus deferred fees align student and university interests in fund raising to forgive student liabilities. This is new. Currently universities have no financial incentive to fund raise to reduce student liabilities to the state. This is important. In the US it is well appreciated that fund raising directly for student support is the easiest type of fund raising from alumni. We see very little of this kind of direct fundraising in UK universities, who typically fundraise for academic posts, buildings or occasionally extra living cost cash via bursaries.

\section{C.2.2 A critique of this approach: wealth effect}

Of course deferred fees have side-effects. A university should be rewarded for generating large private benefits. But (a) University would benefit from high percentage of upfront payers. This has nothing to do with the private benefit generated at the University. (b) Women tend to have lower life time earnings than men, this system may incentivise sex discrimination at admission. (c) On average humanities students have lower life time graduate earnings than scientifically trained graduates, so this system will generate disappointing income for universities with high numbers of such students.

Sexism is illegal, so perhaps point $b$ is less pressing. Needs blind admissions may deal with the recruitment issue in point c. Training students in humanities generate many other benefits and is a choice made by the universities, money is not everything. But why should a university get extra funds just because wealthy families send their children there? 
Table C $2 \mathrm{~b}$ illustrates this by comparing a university with $50 \%$ upfront payments to one with $15 \%$. It assumes of those who do not pay upfront, $60 \%$ eventually pay over 25 years at both universities. Thus the evidence is that they produce the same private benefit, but one university gets more money due to having students with better-off parents. This seems unfair.

\begin{tabular}{|c|c|c|c|}
\hline Source of payment & \multicolumn{2}{|c|}{ Upfront payment \% } & Upfront payment \% \\
\hline & $\underline{15 \%}$ & $\underline{50 \%}$ & $\underline{50 \%}$ \\
\hline HEFCE grant \& funded fees & f6k & f6k & f6k \\
\hline Upfront payment of deferred fees & $£ 0.45 \mathrm{k}$ & f1.5k & f1.5k \\
\hline Scholarship program & & & $-£ 0.42 k$ \\
\hline Deferred fees paid over 25 year period & $£ 1.53 \mathrm{k}$ & f0.9k & $f 0.9 \mathrm{k}$ \\
\hline Total & f7.98k & f8.4k & f7.98k \\
\hline
\end{tabular}

Table C2b. Source: author's own calculations. Assumes of all borrowing, $60 \%$ is repaid.

I think universities should get the credit for their philanthropic efforts, but not for having larger upfront payment rates compared to the national average. How big is the "wealth effect" at a particular university? I will assume that the university's upfront payers would have had the same private benefit as the students at that university who did not pay upfront ${ }^{32}$. I will measure things through the forgiveness rate of $40 \%$ (i.e. $60 \%$ of borrowing is repaid) and the difference between University's upfront percentage and the National upfront percentage which is $35 \%$. Then the "wealth effect" would be ("excess upfront proportion" xforgiveness rate at the universityxface value of fee) $0.35 \times 0.4 \times f 3 \mathrm{k}=f 0.42 \mathrm{k}$. This is relatively small and is due to the low forgiveness rate at the university (note if there was no forgiveness then there would be no wealth effect, whatever the percentage of upfront payers, while if all non-upfront payers had their support forgiven then the "wealth effect" would be $0.35 \times f 3 k=f 1.05 k)$. Still, in my view this amount should not appear on the bottom line of the university. One way of doing this is to introduce a scholarship programme, which forgives some student fee liabilities, which is illustrated by the right hand side of Table C2b. Another approach is to make sure these funds are used to drive up undergraduate educational quality at that university for all the students at that university ${ }^{33}$.

\section{C.3 From the state's perspective}

The role of the state would be to (i) run an efficient financial support system, (ii) fund the student financial support which is forgiven, (iii) fund the HEFCE grant, (iv) fund HEFCE's subject premiums. The first is done through the SLC. The second and third issue merit funding as education typically generates common goods. The state is not affected at all by deferred fees.

The state may have an interest in providing direct subsidies to particular groups of students, such as those from financially poorer backgrounds. It could do this by paying universities a "pupil premium", which would sit beside the deferred fee. A cheaper option is to add to this a claw back, so if the graduate from a poorer background goes on to pay the university in full the deferred fee then the government claws back its pupil premium from the university. Thus the state would be risk sharing with the university for students from poorer backgrounds.

\footnotetext{
${ }^{32}$ In statistics this would be to say that the private benefit of non-upfront payers is missing at random.

${ }^{33}$ A method which does not work is to provide funds to universities with low upfront payments (i.e. to transfer money between universities), for these universities may also have high rates of forgiven fees, and supporting universities in this way incentivises them to raise their own fees in order to attract this kind of support.
} 


\section{C.4 From a parent's perspective}

Around $15 \%$ of students are financed to go to their university by their parents. It could be that some of the living costs of many more are aided by generous parents. This contribution helps the student, but also the state. With deferred fees it will also helps the student's university.

Section 1.4 discusses various ways of encouraging upfront payments, which help all stakeholders.

\section{C.5 From UK plc's perspective}

Around $5 \%$ of UK undergraduates are from the other-EU. I would expect this percentage to increase strongly through time due to the quality of our universities, globalisation and the integration of the EU. The direct financial implications of these students for the UK plc is as follows

- Other-EU students are not entitled to receive cost of living support.

- HEFCE teaching grant is applied to other-EU students. This also applies to premium subjects.

- Other-EU students pay the same tuition fees as UK students, on the same terms. As there are no cost of living support, the fees are paid back first and so forgiveness rates should, in principle, be low as less needs to be repaid. Further, over a half of other-EU students currently seem to pay their fees upfront, compared to around $15 \%$ from the UK.

- HM Customs and Exercise have arrangements with other countries to try to collect the fees of students who work outside the UK. It is unclear to me how effective these arrangements are compared to the case where the graduate works in the UK.

- My understanding is that UK universities are not allowed to discriminate against applicants on the grounds of nationality within the EU due to the legislation on the single market (from a legal position, providing educational services is like selling any other good).

Suppose we think of this solely as a simple economic transaction. Then (i) UK gains by other-EU students spending around $f 7 k-f 8 k$ on cost of living in the UK, (ii) UK gains by students paying $f 3.2 k$ fees to the state or upfront to the university, (iii) UK loses by the students being subsidised by the HEFCE teaching grant and subject premiums.

Overall this is probably a small net gain in most subjects where the HEFCE teaching grant is small, but a financial loss in the case of some science and medical subjects.

Increasing cost of living support for UK students has no impact on other-EU students. Reducing the HEFCE teaching grant and increasing funded fees leads to an improvement for UK plc. Allowing deferred fees is a direct benefit to UK plc.

Hence the reforms advocated in this paper should directly improve the financial position of the UK as a whole, rather than simply redistributing wealth around the country. Clearly an increase in fees by $f 1 k$ per year per student should bring into UK universities around an extra $f 50 \mathrm{M}$ from sources outside the UK. 


\section{Appendix. Directly responding to the evaluation criteria}

I believe on every stated criteria the above system passes.

\section{D.1 Higher education system as a whole}

\section{D.1.1 Will be durable in the long term, and responds to the short-term pressures of the current economic situation}

There seems to be a near a consensus to charge an interest rate around the government cost of borrowing. This makes the student financial support system much more efficient in the long-run, although the savings will not immediately appear in the higher education budget.

This gain in efficiency allows us to remove the means testing of grants and bursaries, replacing them with a simple universal student financial support system. This reduces the PSBR and improves net fee income of universities, the latter reduces the pressure some universities have to want to increase fees in order to stabilise their books. It also greatly simplifies the system, which will reduce administrative costs at universities and at the SLC. It also helps potential students who currently facing a very complicated system of supporting their cost of living.

Removing the rate subsidy on student financial support should increase the number of families who pay upfront. Currently this covers around $15 \%$ of students. I have also advocated making it easier for families to pay fees using monthly direct debits, reducing the liquidity constraint some may face.

Table 1 provides a summary of my calculations of these basic changes. I would hope that some of these savings could be used to improve participation, which is currently being denied to over 100,000 young people who wish to go to university. Further reductions in the deficit can be made by potentially reducing the HEFCE grant directly (as universities net fees will rise due to the removal of bursaries funded from fee income) or by reducing the HEFCE grant and increasing the level of fees to compensate. I hope both of these changes could be avoided but I would currently prioritise increasing the number of student places.

I have also advocated that universities should be allowed to charge deferred tuition fees. These would be paid to the university by its most prosperous graduates and involve no role for the state. I argue this is a better way to design any future fee rises and introduce genuinely private contributions into the system.

Finally, I have argued to make the HEFCE teaching grant visible to students. This makes no difference economically, but it should help in improving the public awareness of the generosity of the UK system.

\section{D.1.2 Fosters the flexibility and autonomy of providers and the diversity of higher education provision}

By allowing universities to charge deferred fees, one institution generating extra income will not come at the expense of another institution. Instead the deferred fee level should be set at the right level for each higher education community: its university faculty, its students and its alumni.

\section{D.1.3 Is affordable to students and the state}

In section 2 I show how the changes I have advocated should improve the fiscal position, and set up the system to be efficient in the longer term when we hope it will be substantially larger. 
I have discussed three aspects of affordability to students. First the current system of cost of living support is inadequate and this potentially damages participation and induces high drop out rates. With the removal of the rate subsidy, there is less need to ration student support. Hence I think the

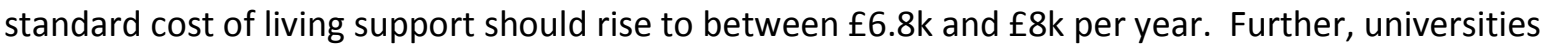
should not be charging "bench fees" or high "material costs" for teaching, tuition fees should be all inclusive.

Finally, students would know that if they need student financial support then as graduates they will only be asked to pay it back in a way which relates to affordability using an income contingent system. I argued in Shephard (2010) to reduce the payment to improve affordability, in response to the interest rate increasing.

\section{D.1.4 Is practicable to implement and enforce}

By removing grants and bursaries this system is much simpler to students, the Student Loan Company and universities.

Deferred fees can be collected through the SLC in the usual way, in effect the university would own a part of the SLC loan book. As a result each university with deferred fees would then receive an annual check from the SLC of graduate payments of deferred fees. It can then do what it likes with that cheque.

\section{D.1.5 Enhances the UK's competitiveness in global higher education markets}

At the moment the UK funding system damages UK competitiveness in increasingly competitive higher education markets. The end game for our current inefficient financial system is that we will be driven to a standardise system of large classes which has little contact with active researchers or dedicated professional teachers. Wealthy families will opt out and their kids will go to the US universities who have little concern over access issues for UK students (e.g. for 2010-2011 Harvard College has offers out to 30 students, of which 5 are from Eton College and nearly everyone else on the list is privately educated).

By making all universities receive basically the same funding we do not allow institutions to follow their own path to excellence, unless they have other resources which they can draw upon to fund them. Of course some of these extra resources are drawn from research or graduate teaching income and this will eventually damage the reputation of our universities.

Deferred fees could overcome this. This will help us not just protect the quality of undergraduate education, but it will stop the damage currently being done to graduate education and research.

\section{D.1.6 Satisfies students' desire for learning}

I am horrified that during the current recession the higher education funding system is so inefficient that we have been unable to allow hundreds of thousands of young people to go to university. Instead many of these young people have been unemployed.

Under this system any UK student who wishes to go to university can get the funding to do so.

\section{D.1.7 Can be expected to enhance employer involvement}

Deferred fees incentivise universities to fund raise to provide student support to students. This may come from philanthropic sources or from employers through sponsorship. Employees who are 
studying part-time could potentially being given access to an easy to use salary sacrifice scheme to reduce the costs of their tuition costs or those on lower incomes could be given access to the Student Support System for their tuition costs.

\section{D.2 Participation}

\section{D.2.1 Offers a robust mechanism for widening participation \& ensuring fair access}

I have suggested improving financial support for the cost of living in order to reduce the liquidity constraint some poorer potential students face and making the system much simpler which should also improve access. By making the system economically more efficient, more student places can be provided, even in fiscally difficult times. I am keen to ensure that there are no unexpected "bench fees" and that universities have a responsibility to provide financial support if the living expenses of their students are driven out of the reach of ordinary students.

I have argued to make the HEFCE teaching grant visible to students. This should help demonstrate the support the state is providing to the student.

\section{D.2.2 Is easy for students and potential students to understand \& use}

The extension of financial support for the cost of living and the removal of complicated grants and bursaries makes the proposed system much simpler to potential students to understand. The available resources to support cost of living will be a single number, which could be set somewhere between $f 6.8 \mathrm{k}$ and $\mathrm{f} 8 \mathrm{k}$.

By simplifying the system the SLC's job becomes much easier, which reduces the risk students current face of it being unable to carry out its job.

I would also urge the Review to think about making it easier for the parents (and later employers) who can afford to fund tuition fees to do so. I have shown this helps all those involved in higher education, not just the children of the better-off parents. I have proposed various ways this can be done, including payment by direct debit, savings accounts and salary sacrifice schemes.

I also think language is important. Renaming the Student Loan Company, the Student Support Company would be more accurate. The use of the words loans and debt ignore the fact that everything is income contingent.

\section{D.3 Quality}

\section{D.3.1 Incentives, efficient and increased quality}

The system is designed to be efficient, by (i) removing the rate subsidy, (ii) removing bursaries and grants, funding cost of living through the financial support system, (iii) providing no subsidy from the state to increase tuition fees.

Deferred fees reward quality, but focusing on measuring the private benefit each graduate has received from university.

\section{D.3.2 Enables or stimulates innovation}

This system allows universities to follow their own path to excellence. I hope to see highly prestigious teaching only colleges developed, based on smallish group teaching along the lines of Swarthmore or Haverford in the US. These are not cheap to run and simply cannot develop under 
the current method of funding unless the institute is a private university (which raises important access issues to do with exclusion by means testing discussed above).

\section{D.4 Sustainability}

\section{D.4.1 Improves the long-term sustainability of the student finance system}

By removing the interest rate subsidy, by charging the Government's cost of borrowing, we reduce the rate at which the RAB is currently climbing and so reduce the pressure on future higher education budgets.

By converting bursaries and grants into loans, we reduce the immediate pressure on the higher education budget and we increase the net funded fees income received by universities. The latter reduces the pressure on the system for funded fees to increase and improves the finances of our universities.

By allowing deferred fees we leave available a pressure value for institutions who wish to provide more expensive forms of education. These universities would have to take responsibility for providing financial support for their students so that the universities are financially accessible to all.

\section{D.4.2 Reduces administrative burden on institutions and public bodies}

The removal of means tested funding of cost of living through bursaries and grants will dramatically simplify the job of the SLC and reduce complexity for universities. The role of HEFCE will diminish as more resources for higher education come directly from graduates rather than through HEFCE. Hopefully the admin burden HEFCE currently generates will fall.

The role of the Office of Fair Access should change. Instead of overseeing bursaries, it should be a champion for increasing information for potential students about what universities offer and assessing the work universities do with schools to help support access.

\section{D.4.3 Ensures any increase in private contributions does not lead to additional costs to the state \\ Deferred fees have no fiscal implications at all. Hence any new money generated by them go directly from the parents or prosperous graduates to the university.}

